\title{
The impact of systematized physical activity on
} parameters of health-related physical fitness in schoolchildren aged 8 to 11 years

\author{
Impacto da atividade esportiva organizada sobre parâmetros da aptidão física \\ relacionado à saúde de escolares de 8 a 11 anos de idade
}

\section{AUTHOR'S \\ Marcelo José Resende Gonçalves ${ }^{1}$ (D) \\ Camila Ramos dos Santos ${ }^{1,2}$ (D) \\ Carla Cristiane da Silva ${ }^{1}$ (D) \\ 1 Grupo de Estudos em Adaptações Biológicas do Treinamento Infantil-GEABTI. Universidade Estadual do Norte do Paraná, Jacarezinho, Paraná, Brasil. \\ 2 Diretoria de Operações Acadêmicas da Graduação Presencial, Ciências Biológicas e Saúde, Universidade do Norte do Paraná, Londrina, Paraná, Brasil.}

\section{CORRESPONDING}

Carla Cristiane da Silva ccsilva@uenp.edu.br

Universidade Estadual do Norte do Paraná (UENP). Alameda Padre Magno, no 841,

Nova Jacarezinho, Paraná, Brazil.

Zip Code: 86400-000.

DOI

$10.12820 /$ rbafs. $24 \mathrm{e} 0072$

\section{(c) BY-NC-SA}

This work is licensed under the Creative Commons Attribution-NonCommercial-ShareAlike 4.0 International License.

\begin{abstract}
The objective of this study was to verify if there is an impact of an additional program of sports activities (GSA) in school Physical Education classes on parameters of physical fitness related to the health of children. A quasi-experimental study was carried out, including 73 children, 8 to 11 years of age, of both sexes. The intervention took place over four weeks, with two weekly sessions of training or class, lasting 50 to 60 minutes per session. The children were allocated into two groups: a group that performed the Physical Education classes exclusively (GPE, $\mathrm{n}=39$ ); and a sports activities group (GSA, $n=34)$. The sports activities included passes, reception, pitches, dribbling, and running. Physical fitness was investigated by the Fitnessgram test in the pre- and post-intervention moments. Generalized Estimating Equations were used to compare the physical fitness tests between the pre and post moments (intragroup), and the impact of the intervention was verified by the intergroup analysis. The intragroup results showed that the GSA presented significant improvements in all physical fitness tests $(\mathrm{p}<0.01)$, as well as reduction in relative fat and BMI $(\mathrm{p}<0.05)$. However, the GPE demonstrated worsening results in the abdominal test $(\mathrm{p}=0.019)$ and an increase in relative fat $(p=0.001)$. In the intergroup analysis, there were significant differences in the BMI and aerobic endurance test, with superiority in the GSA $(p=0.030)$. It was concluded that the program with sports activities was effective in improving physical fitness levels, while PE classes in isolation were not sufficient to guarantee improvement in physical fitness related to health.
\end{abstract}

Keywords: Motor activity; School health; Physical education; Physical fitness.

RESUMO

O objetivo deste estudo foi verificar se existe impacto de um programa adicional de atividades esportivas (GSA) às aulas de Educação Física (EF) escolar sobre parâmetros da aptidão física relacionada à saúde de crianças. Estudo quase - experimental que envolveu 73 crianças, de 8 a 11 anos de idade, de ambos os sexos. A intervenção ocorreu durante quatro semanas, com duas sessões semanais de treinamento ou aula, com duração de 50 a 60 minutos por sessão. As crianças foram alocadas em dois grupos: grupo que realizou as aulas de Educação Física $(G P E, n=39)$ exclusivamente; e grupo de atividades esportivas $(G S A, n=34)$. As atividades esportivas incluiram jogos pré-desportivos, incluindo passes, recepção, arremessos, dribles e corridas. A aptidão física foi investigada pelo Fitnessgram nos momentos pré e pós-intervenção. As Equações de Estimativa Generalizadas foram utilizadas para comparar os testes de aptidão física entre os momentos pré e pós (intragrupos), e o impacto da intervenção foi verificado pela análise intergrupos. Os resultados intragrupo revelaram que o GSA obteve uma melhora significativa em todos os testes de aptidão física $(p<0,01)$, além da redução da gordura relativa e no IMC $(p<0,05)$. No entanto, o GPE demonstrou piora no teste abdominal $(p=$ $0,019)$ e aumento na gordura relativa $(p=0,001)$. Na análise intergrupos, houve diferenças significativas no IMC e no teste de resistência aeróbia, com superioridade no GSA $(p=0,030)$. Conclui-se que o programa com atividades esportivas foi efetivo na melhora dos niveis de aptidão física, enquanto que as aulas de EF não foram suficientes de forma isolada para garantir melhora na aptidão física relacionada à saúde.

Palavras-chave: Atividade motora; Saúde do escolar; Educação física; Aptidão física.

\section{Introduction}

It is widely recognized in the literature that adequate physical activity in childhood and adolescence is essential for good health ${ }^{1}$. However, the majority of children and adolescents (5-17 years) do not meet the minimum recom- mendations to practice 60 minutes a day of moderate to vigorous physical activity ${ }^{2}$. A reduction in the level of habitual physical activity during childhood and adolescence is associated with increased body weight, as well as reduced performance in health-related physical fitness tests ${ }^{3,4}$. 
A low level of physical fitness in children and adolescents may be linked to low motor competence scores, characterized by proficiency in locomotion and object control skills ${ }^{4}$. As a result, low engagement in regular physical activity practice is observed ${ }^{4}$.

Previous studies have demonstrated that children engaged in organized sports presented better scores in physical fitness and motor competence, as well as a higher level of daily physical activity when compared to children who were not engaged in these practices ${ }^{5,6}$.

Low levels of physical activity have been reported by the World Health Organization as the fourth risk factor for global mortality ${ }^{7}$. On the other hand, increased moderate to vigorous daily physical activity promoted positive health outcomes in children aged 8 to 11 years $^{8}$. In addition, 60 minutes of daily physical activity during childhood and adolescence may improve the risk profiles for cardiovascular and metabolic disease; increase bone mineral density; reduce symptoms of depression; and improve socialization, and children's emotional and cognitive well-being ${ }^{8}$.

In this context, Lee and collaborators ${ }^{9}$ indicated that engaging in sports practices helps to reduce health spending ${ }^{9}$. The results of this study demonstrated that $75 \%$ of US children, aged 8 to 11 , performing moderate to high intensity sports three times a week generated savings of approximately $\$ 16.6$ billion in direct medical costs 9 . However, it is important to inquire whether the practice of sports incorporated during Physical Education (PE) classes in the school environment has an effect on the physical fitness levels of children and adolescents. A previous study in Brazil reported that PE classes did not demonstrate sufficient results to ensure adequate levels of physical fitness activity when focusing on children's health ${ }^{6}$.

In Brazil, PE is a subject integrated into the pedagogical program of the school, and is characterized as a compulsory curricular component of Basic Education ${ }^{10}$. However, studies have shown that the number of classes per week and the intensity achieved during classes are not sufficient and efficient when compared to extra activities for children to improve physical fitness parameters $^{8,11}$, as they are below the recommendations proposed by the Guidelines for Physical Activity in Childhood ${ }^{12}$. Corroborating these findings, research that analyzed 39 $\mathrm{PE}$ classes found that on average only $25 \%$ of class time was spent on moderate to vigorous physical activity, and there was little motor variation ${ }^{13}$. These results are concerning, as it has been recommended that to improve health status at least $50 \%$ of class time should be spent on moderate to vigorous physical activity ${ }^{13}$

On the other hand, it is recognized that the PE discipline in school should be highlighted, since one of its roles is to promote the incorporation of healthy habits during childhood and adolescence ${ }^{14}$. Researchers in the area recognize that sports activities additional to $\mathrm{PE}$ classes are characterized as a possible strategy to assist in the enhancement of physical fitness components ${ }^{11}$. Thus, one possible method to ensure good levels of physical fitness is through school interventions, such as practices that encourage participation in active and recreational games outside regular school hours in order to arouse greater interest in the practice of movement ${ }^{15}$. In this regard, an investigation of 1,119 children with a mean age of 7.6 years of both sexes ( $54 \%$ boys; $47 \%$ girls) from 32 German schools found that children who were included in sports once or twice a week demonstrated superiority in sitting and reaching, 6-minute running, and medicine ball throwing ${ }^{16}$. Supporting this evidence, 1119 (53\% male, $47 \%$ female)second-grade children $(7.60 \pm 0.4$ years) underwent a 12 -week intervention that included organized sports activities in the school environment. The results showed significant improvement in cardiorespiratory fitness and an increased level of physical activity on school days measured by a pedometer ${ }^{16}$.

In this scenario, the objective of this study was to verify if there is an impact of a program that adds organized sports activities to school PE classes on parameters of health-related physical fitness in children from 8 to 11 years of age.

\section{Methods}

This study was carried out with a quasi-experimental (pre/post-test) design including a convenience sample of 73 schoolchildren aged 8 to 11 years, 42 girls and 31 boys. The children were allocated into two groups: one that exclusively attended the school's PE classes (GPE); and another that in addition to the PE classes performed sports activities organized in the time they did not attend school (GSA). The study was proposed by a PE teacher in the school system, linked to two different schools. All procedures were performed after approval by the Human Research Ethics Committee of the State University of Londrina (CAAE 62267516.2.0000.5231).

One of the schools was chosen for convenience for inclusion in a program of organized sports activities (GSA) during the period when the children were not 
at school, while in the other school the classes took place normally (GPE), without any communication between the participants. For each school, a normal class of children was selected, without excluding any child, and there were no dropouts during the four weeks of intervention. In an interview prior to data collection, the teacher responsible for the project confirmed that none of the students involved in the study had participated in any systematic physical or sports activity in the previous six months. The teacher selected the classes and taught the activities in both groups. The PE classes were held twice a week, lasting $60 \mathrm{~min}-$ utes each class (Chart 1$)$.

The GSA performed the intervention for four weeks, with sessions twice a week on alternate days, each session lasting 50-60 minutes. The activities included in the intervention are described in Chart 2.

There are several school intervention models used as strategies to boost energy expenditure and result in improved physical fitness ${ }^{18}$. In the current study we chose the model of sports activities to ensure the involvement of most students, with moderate to high intensity of effort, and motivation during the practice of pre-sport games ${ }^{19}$.

To verify the impact of the additional sports activities program on physical fitness parameters, evaluations were performed before and after the four week intervention. The procedures are illustrated in flowchart 1.

Chart 1-Activities developed in the group that participated exclusively in Physical Education classes, lasting 60 minutes per session twice weekly for 4 weeks (8 sessions).

\begin{tabular}{|c|c|c|c|}
\hline Session & Activities & Session & Activities \\
\hline 1 & $\begin{array}{l}\text { Warm-up: } 20 \text { minutes- recreational activities- catch, steal flag. } \\
\text { Cooperative and competitive games: } 30 \text { minutes- dodge ball, } \\
\text { human current. } \\
\text { Calm down: } 10 \text { minutes- clapping. }\end{array}$ & 5 & $\begin{array}{l}\text { Team and individual race circuits- } 20 \text { minutes. } \\
\text { Ball handling and control circuits- } 20 \text { minutes. } \\
\text { Play activities for learning throwing and catching: } 20 \text { minutes- pre- } \\
\text { sports, throwing and catching methods, dodge ball. }\end{array}$ \\
\hline 2 & $\begin{array}{l}\text { Introduction to track and field: } 20 \text { minutes - Track and field events. } \\
\text { Team and individual race circuits- } 20 \text { minutes. } \\
\text { Playful activities for learning throwing and catching: } 20 \text { minutes } \\
\text { - pre-sports, body control, throwing and catching methods. }\end{array}$ & 6 & $\begin{array}{l}\text { Introduction to collective modalities: } 20 \text { minutes- Volleyball and } \\
\text { basketball. } \\
\text { Ball handling and control circuit activities with racket - } 20 \text { minutes. } \\
\text { Play activities for touch and serve - } 20 \text { minutes - pre-sport (mini- } \\
\text { volleyball). }\end{array}$ \\
\hline 3 & $\begin{array}{l}\text { Introduction to collective sports: } 20 \text { minutes- Volleyball and } \\
\text { basketball. } \\
\text { Ball handling and control circuits- } 20 \text { minutes. } \\
\text { Recreational activities for throwing, passes, and dribbling- } 20 \\
\text { minutes- pre-sport basketball. }\end{array}$ & 7 & $\begin{array}{l}\text { Introduction to collective sports: } 20 \text { minutes- Volleyball and basketball. } \\
\text { Ball handling and control circuits- } 20 \text { minutes. } \\
\text { Play activities for touch and serve - } 20 \text { minutes - pre-sport (mini- } \\
\text { volleyball). }\end{array}$ \\
\hline 4 & $\begin{array}{l}\text { Introduction to collective modalities: } 20 \text { minutes- Volleyball and } \\
\text { basketball. } \\
\text { Ball handling and control circuits- } 20 \text { minutes. } \\
\text { Play activities for touch and serve - } 20 \text { minutes - pre-sport } \\
\text { (mini-volleyball). }\end{array}$ & 8 & $\begin{array}{l}\text { Cooperative and competitive games: } 20 \text { minutes-dodge ball, } \\
\text { Circuits of balance, body notion, and laterality: } 20 \text { minutes. } \\
\text { Ball handling and control circuit activities with racket }-20 \text { minutes. }\end{array}$ \\
\hline
\end{tabular}

Chart 2 - Intervention: sports activity protocol lasting 50 minutes per session for 4 weeks (8 sessions).

\begin{tabular}{|c|c|c|c|}
\hline Session & Activities & Session & Activities \\
\hline 1 & $\begin{array}{l}\text { Warm up: } 10 \text { minutes - light running, stretching. } \\
\text { Basic Techniques I: } \\
20 \text { minutes - passes, reception, pitches. } \\
20 \text { mins Pre-sport and competitive games- Dodge ball, catch- } \\
\text { the-ball, hit the hula hoop. }\end{array}$ & 5 & $\begin{array}{l}\text { Warm up: } 10 \text { minutes - light running, passes, and reception. } \\
\text { Basic Techniques II: } \\
20 \text { minutes - Feints (body and arm initiation) and dribbling. } \\
\text { Recreational activities for sports initiation: } 20 \text { minutes- pre-sports, } \\
\text { dribbling, defensive notions. }\end{array}$ \\
\hline 2 & $\begin{array}{l}\text { Warm up: } 10 \text { minutes - light running, passes, and reception. } \\
\text { Basic Techniques II: } \\
20 \text { minutes - Feints (body and arm initiation) and dribbling. } \\
\text { Recreational activities for sports initiation: } 20 \text { minutes- pre- } \\
\text { sports, dribbling, defensive notions. }\end{array}$ & 6 & $\begin{array}{l}\text { Warm up: } 10 \text { minutes - light running, catching ball. } \\
\text { Basic Techniques II: } \\
20 \text { minutes - Feints and dribbling with individual marking. } \\
\text { Play activities for group initiation: } 20 \text { minutes. }\end{array}$ \\
\hline 3 & $\begin{array}{l}\text { Warm up: } 10 \text { minutes - light running, stretching. } \\
\text { Basic Techniques: } \\
20 \text { minutes - passes, reception, pitches. } \\
20 \text { mins pre-sport and competitive games- Dodge ball, catch- } \\
\text { the-ball, hit the hula hoop. }\end{array}$ & 7 & $\begin{array}{l}\text { Warm up: } 10 \text { minutes - light running, passes, and reception. } \\
\text { Basic Techniques II: } \\
20 \text { minutes - Feints (body and arm initiation) and dribbling. } \\
\text { Recreational activities for sports initiation: } 20 \text { minutes- pre-sports, } \\
\text { dribbling, defensive notions. }\end{array}$ \\
\hline 4 & $\begin{array}{l}\text { Warm up: } 10 \text { minutes - light running, catching ball. } \\
\text { Basic Techniques II: } \\
20 \text { minutes - Feints and dribbling with individual marking. } \\
\text { Play activities for group initiation: } 20 \text { minutes. }\end{array}$ & 8 & $\begin{array}{l}\text { Warm up: } 10 \text { minutes - light running, catching ball. } \\
\text { Basic Techniques II: } \\
20 \text { minutes - Feints and dribbling with individual marking. } \\
\text { Play activities for group initiation: } 20 \text { minutes. }\end{array}$ \\
\hline
\end{tabular}


To calculate nutritional status according to BMI, body mass and height measurements were taken. For body mass a Power Pack scale with 100 gram precision was used and for height a stadiometer coupled to the scale. In addition, the relative fat was calculated by the sum of the triceps and calf subcutaneous folds using a Cescorf brand skinfold caliper and the result was interpreted by the sex and age-specific table of Fitnessgram ${ }^{20}$. Evaluations were performed by a single experienced evaluator and skinfold measurements were rotationally taken between the anatomical points according to Fitnessgram, and replicated three times. The measurements were recorded by an independent annotator. The measurements were performed in the right hemibody of the children and the mean value of the three measurements was used.

Health-related physical fitness was investigated using the Fitnessgram ${ }^{20}$ battery of physical tests, and the abdominal muscle strength and endurance, aerobic endurance, and flexibility tests were applied at the start and end of the four-week intervention. Prior to the start of the project, approximately one week, a single trained evaluator applied all the tests to familiarize the children with the tests. In the following week, characterized as the pre-intervention moment, the tests were repeated following the specific instructions for their performance $\left(\right.$ Fitnessgram $\left.^{20}\right)$. For each test, three attempts were performed and the best performance was used. An annotator, without information on which group the children belonged to (evaluator blinding), noted the results and later transmitted these results to the statistician.

In the descriptive analysis of the data, two procedures were applied. In the first, the variables at the pre-intervention moment were compared between the groups (Table 1) in order to confirm the absence of differences between the groups. For this, the Kolmogorov-Smirnov test was performed to verify the normality of the data. The data did not present normal distribution and thus, the nonparametric Mann-Whitney test was applied. Subsequently, to verify the effect of the fourweek intervention between the groups, the Generalized Estimating Equation (EEG) test was used. This analysis was performed since the data distribution did not meet the assumption of normality or sphericity. All procedures were performed using the SPSS 20.0 statistical package, adopting a significance level of $\mathrm{p} \leq 0.05$.

\section{Results}

Of the 73 volunteers selected for this study, 42 were female and 31 male. The exclusive PE class group consisted of 39 children, 24 girls and 15 boys, with a mean age of $10.06 \pm 0.77$ years; and the other group included 34 children, consisting of 18 girls and 16 boys, who performed the sports activities in the period when they were not at school, with a mean age of $9.04 \pm 0.96$ years. There were no refusals or withdrawals of any participants during the selection and intervention processes.

Table 1 presents the general characteristics of the participants in each group at the pre-intervention moment. There was a statistically significant difference between the groups in the chronological age variable at the pre-intervention moment, with higher values in the GPE, and for the fat variable, significantly higher values can be observed in the GSA.

Table 2 presents the mean values of the variables $\mathrm{BMI}$, relative fat, and physical fitness tests between the pre and post intervention moments in the intragroup analysis (pre versus post comparison) and the comparison of the intervention effect between groups (intergroup comparison).

In the intragroup analysis, the GSA demonstrated a significant improvement in all physical fitness tests ( $\mathrm{p}$ $<0.01$ ), as well as a reduction in relative fat and BMI $(\mathrm{p}<0.05)$. However, the GPE presented worsening performance in the abdominal test $(p=0.019)$ and an increase in relative fat $(\mathrm{p}=0.001)$.

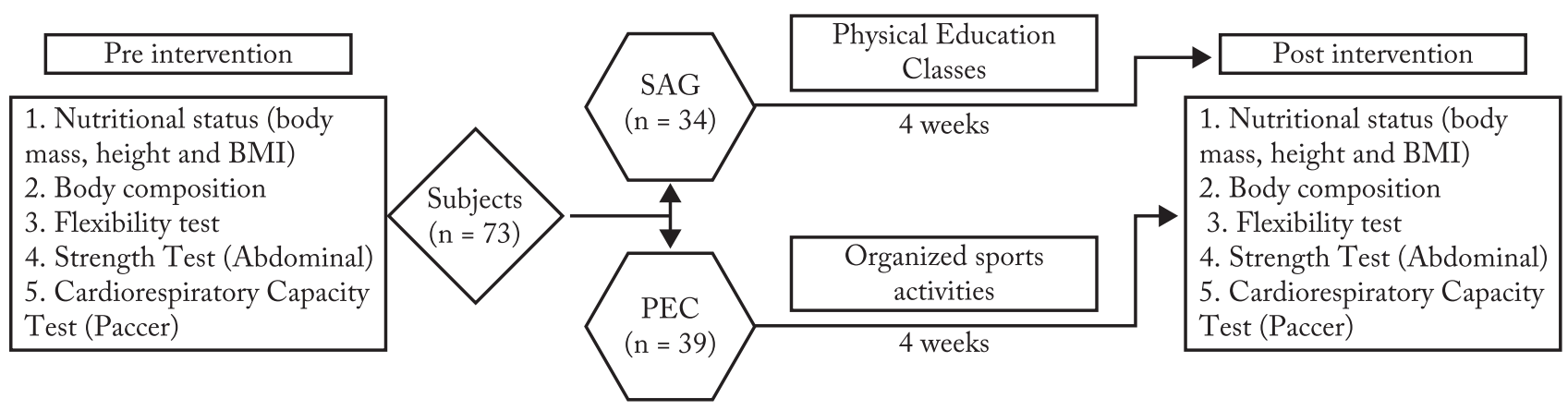

Figure 1 - Flowchart of the study steps. 
Table 1 - General characteristics of the participants in each group at the pre-intervention moment (median and interquartile range values), Andirá, 2016.

\begin{tabular}{lccc}
\hline Variables & $\begin{array}{c}\text { GPE }(\mathrm{n}=39) \\
\text { Median (Q1-Q3) }\end{array}$ & $\begin{array}{c}\text { GSA (n=34) } \\
\text { Median (Q1-Q3) }\end{array}$ & P Value \\
\hline Age (years) & $10.02(9.03-10.07)$ & $9.04(8.05-10.20)$ & $0.010^{*}$ \\
TBM (kg) & $32.00(27.00-41.50)$ & $35.20(29.50-45.60)$ & 0.106 \\
Height $(\mathrm{m})$ & $1.41(1.34-1.45)$ & $1.41(1.37-1.49)$ & 0.543 \\
BMI $\left(\mathrm{kg} / \mathrm{m}^{2}\right)$ & $16.76(14.80-19.01)$ & $17.62(15.02-23.00)$ & 0.101 \\
Relative fat (\%G) & $24.00(17.20-28.90)$ & $27.95(21.00-34.10)$ & $0.040^{*}$ \\
Flexibility (cm) & $24.00(19.00-27.00)$ & $23.50(17.00-26.00)$ & 0.912 \\
Abdominals (units) & $19.00(12.00-28.00)$ & $17.00(11.00-24.00)$ & 0.333 \\
Aerobic endurance $(\mathrm{m})$ & $16.00(9.0-24.00)$ & $21.50(11.00-31.00)$ & 0.095 \\
\hline
\end{tabular}

*P values obtained with the Mann-Whitney test $\mathrm{p} \leq 0.05 ; \mathrm{M}=$ median; $(\mathrm{Q} 1-\mathrm{Q} 3)=$ interquartile range; $\mathrm{TBM}=$ total body mass; $\mathrm{BMI}=$ body mass index; $\mathrm{GPE}=$ physical education group; GSA = sports activities group.

Table 2 - Study variables compared at pre and post intervention moments for each group (intragroup analysis) and comparisons between groups (intergroup) to verify the effect of the intervention, Andirá, 2016.

\begin{tabular}{|c|c|c|c|c|c|c|c|}
\hline \multirow[b]{2}{*}{ Variables } & \multicolumn{3}{|c|}{ GPE (n = 39) } & \multicolumn{3}{|c|}{ GSA $(n=34)$} & \multirow[b]{2}{*}{$\begin{array}{c}\mathrm{p} \\
\text { (intergroup) }\end{array}$} \\
\hline & $\begin{array}{c}\text { Pre } \\
(\text { Mean } \pm \mathrm{SD})\end{array}$ & $\begin{array}{c}\text { Post } \\
(\text { Mean } \pm \mathrm{SD})\end{array}$ & $\begin{array}{c}\mathrm{p} \\
\text { (intragroup) }\end{array}$ & $\begin{array}{c}\text { Pre } \\
(\text { Mean } \pm \mathrm{SD})\end{array}$ & $\begin{array}{c}\text { Post } \\
(\text { Mean } \pm \mathrm{SD})\end{array}$ & $\begin{array}{c}\mathrm{p} \\
\text { (intragroup) }\end{array}$ & \\
\hline BMI $\left(\mathrm{kg} / \mathrm{m}^{2}\right)$ & $17.10 \pm 2.91$ & $17.01 \pm 2.91$ & 0.454 & $19.28 \pm 4.89$ & $19.08 \pm 4.76$ & $0.004^{*}$ & $0.023^{*}$ \\
\hline Relative fat (\%) & $24.14 \pm 8.61$ & $25.22 \pm 8.43$ & $0.001^{*}$ & $28.56 \pm 9.72$ & $26.86 \pm 8.97$ & $0.023^{*}$ & 0.141 \\
\hline Flexibility $(\mathrm{cm})$ & $22.77 \pm 6.32$ & $22.46 \pm 5.22$ & 1.000 & $22.32 \pm 7.55$ & $25.03 \pm 8.68$ & $0.001^{*}$ & 0.531 \\
\hline Abdominals (units) & $20.46 \pm 10.42$ & $19.33 \pm 10.09$ & $0.019^{*}$ & $18.09 \pm 8.89$ & $21.03 \pm 8.90$ & $0.001^{*}$ & 0.860 \\
\hline Aerobic endurance $(\mathrm{m})$ & $18.10 \pm 11.85$ & $17.21 \pm 10.68$ & 0.091 & $22.18 \pm 11.85$ & $24.88 \pm 12.22$ & $0.001^{*}$ & $0.030^{*}$ \\
\hline
\end{tabular}

*P values obtained through the Generalized Estimation Equations; GPE = physical education group; GSA = sports activities group; $T B M=$ total body mass; $\mathrm{BMI}=$ body mass index.

When verifying the effect of the intervention between the groups (intergroup), significant differences were identified in two variables in this study. In BMI significant differences were observed, with higher values in the GSA ( $p=0.023)$, and in the aerobic endurance test significant superiority $(p=0.030)$ was found in the GSA when compared with the GPE.

\section{Discussion}

The main findings of this study demonstrated that the four-week sports activity program improved children's performance in the aerobic endurance test and reduced BMI in the GSA when compared to the GPE. In addition, in the intragroup analysis, the GSA presented improvement in all physical fitness scores, while, in contrast, the GPE showed significant worsening in the abdominal strength and endurance tests.

These results are similar to the Portuguese study conducted by Trigo et $\mathrm{al}^{21}$, which involved two groups of 11 to 15 year old girls: futsal practitioners and non-practitioners The groups were compared using the Fitnessgram reference values for the 1-mile run, abdominals, arm extension, trunk extension, and sit- ting and reaching tests, as well as BMI and relative fat measurements. The main findings indicated significant differences between futsal practitioners and non-practicing girls, where the group of practitioners was superior regarding weight, BMI, aerobic capacity, strength, trunk extension, and sitting and reaching, in addition to decreased relative fat in the futsal group. Another relevant finding was that futsal practitioners presented higher percentiles within the healthy zone range for all tests performed, except for the elbow flexion test. Through this analysis, the study concluded that, in all Fitnessgram tests performed, the futsal practitioners obtained higher values in the healthy zone range than the values achieved by the group of non-practitioners.

Corroborating these findings, another investigation highlighted the positive impact of out-of-class physical activity on maintaining health-related physical fitness in children and adolescents from different countries $^{22}$. On the other hand, studies with interventions in the school environment have shown that the generalist contents associated with short effective class time and low motivation do not guarantee potentialization of desirable health criteria ${ }^{14,23}$. In this sense, a systematic 
review examined interventions performed in PE classes designed to impact the physical activity level, physical fitness, and/or body composition of school-age children. The results of the 12 included studies demonstrated that half of the studies that evaluated physical fitness presented no significant impact ${ }^{18}$.

Among the possibilities for evaluating physical fitness, the Fitnessgram motor test battery was highlighted, as it has been widely used in several studies with large samples and with equally worrying results regarding $\mathrm{PE}^{21,24}$, that is, $\mathrm{PE}$ classes do not improve the values of the tests applied. In the present study, the results indicated a worsening, after four weeks of PE classes alone, in the values for endurance/abdominal strength and relative fat. According to regulations, PE classes in the school environment are fundamental to improve motor activity in childhood, however, previous studies indicate that the classes offer insufficient amounts of motor activity ${ }^{25,26}$. In this sense, in a recent systematic review with meta-analysis ${ }^{15}$, researchers investigated the proportion of time spent in class devoted to moderate and vigorous physical activity. The results of the 25 studies analyzed demonstrated that the mean percentage of class time spent on moderate physical activity was $40.5 \%$ (ranging from $34.8 \%$ to $46.2 \%$ ). Specifically, looking at the age group of seven to ten years, the mean time spent on moderate activities during $\mathrm{PE}$ classes was $48.6 \%$ (range $41.3 \%$ to $55.9 \%)^{15}$. These class time results are below the recommendations of the Centers for Disease Control (CDC) and the Association for Physical Education (AfPE), which determine that a minimum of $50 \%$ of class time should be spent on moderate physical activity as guidelines for improving health ${ }^{15,27}$. Thus, the authors reinforce that additional strategies and intervention studies are necessary to increase the effective time spent on moderate physical activities during $\mathrm{PE}$ classes at school. One of the factors that receives strong emphasis and is directly linked with the development of physical aptitude is motor competence ${ }^{28,29}$.

Gallota et $\mathrm{a}^{11}$ carried out a study aimed at evaluating the effectiveness of $\mathrm{PE}$ classroom interventions for 5 months in an elementary school class using the Fitnessgram test battery. The sample consisted of 230 children randomly assigned to three groups; two experimental groups with interventions (focusing on sensorimotor development and physical fitness) and another control group focused on PE classes without extra activities during classes. Both experimental groups presented significantly improved physical fitness (arm flexion, ab- dominal, trunk lift, sit and reach) and motor coordination (platform shifting, balance beam, side jump, jump on one leg over an obstacle tests) after the intervention period when compared to the control group, which did not show significant improvement in the tests.

It is important to highlight some limitations that preclude a greater degree of generalization of these findings, for example: the short intervention period; the small sample size; the absence of internal load measurement of activities taught in class and/or training; and the absence of quantitative data on the subjects' habitual and leisure physical activity. Future trials that consider reducing these limitations are important to verify the long-term effectiveness of sports fitness programs on physical fitness, as well as reduce threats to the internal and external validity of inferences.

It was concluded that the program with organized sports activities had a positive and significant impact on aerobic fitness, as well as a reduction in BMI. Thus, these findings indicate that, in the manner applied, organized sports activities are an alternative intervention in $\mathrm{PE}$ classes and extracurricular activities, in order to maximize the active time of classes, promote greater involvement of students in moderate to high intensity activities, and aid motivation during the practice of pre-sports games, as well as enhancing the physical fitness of children. However, further studies should be directed at different intervention strategies during $\mathrm{PE}$ classes and/or during the overall school period and their possible impacts on physical fitness and other health-related outcomes in children. The aim should be to guarantee opportunities for physical practice, focusing on physical fitness and reaching the intensity level recommended by the guidelines. In addition, it is important to impart knowledge needed for a physically active lifestyle and cultivate responsible personal and social elements for improving and maintaining good health.

\section{Conflict of interests}

The authors declare no conflict of interest.

\section{Authors' Contributions}

Gonçalves MJR, conducted the study design, data collection, organization and analysis of statistical data, as well as relevant critical review of intellectual content and approval of the final version. Santos CR, performed the analysis and interpretation of the data, writing and relevant critical review of the intellectual content, approval of the final version. Silva CC, conducted the project design, writing and relevant critical review of intellectual content and final version approval. 


\section{References}

1. Poitras VJ, Gray CE, Borghese MM, Carson V, Chaput JP, Janssen I, et al. Systematic review of the relationships between objectively measured physical activity and health indicators in school-aged children and youth. Appl Physiol Nutr Metab. 2016;41(6 Suppl 3):S197-239.

2. Farooq MA, Parkinson KN, Adamson AJ, Pearce MS, Reilly JK, Hughes AR, et al. Timing of the decline in physical activity in childhood and adolescence: Gateshead Millennium Cohort Study. Br J Sports Med. 2018;52(15):1002-06.

3. Chen W,Hammond-Bennett A, Hypnar A,Mason S.Healthrelated physical fitness and physical activity in elementary school students. BMC Public Health. 2018;18(1):195.

4. Frasen J, Pion J, Vandendriessche J, Vandorpe B, Vaeyens R, Lenoir M, Philippaerts RM. Differences in physical fitness and gross motor coordination in boys aged 6-12 years specializing in one versus sampling more than one sport. J Sci Med Sport. 2012; 30(4),379-86.

5. Lai SK, Costigan SA, Morgan PJ, Lubans DR, Stodden DF, Salmon J, et al. Do school-based interventions focusing on physical activity, fitness, or fundamental movement skill competency produce a sustained impact in these outcomes in children and adolescents? A systematic review of follow-up studies. Sports Med. 2014;44(1):67-79.

6. Santos CR, Silva CC, Marques I. Relationship between physical activity, physical fitness, and motor competence in school children. Motricidade. 2017;13(Suppl 1):76-83.

7. World Health Organization Web site [Internet]. Geneva (Switzerland): World Health Organization; [citado 2018 Jan 4]. Disponível em: http://www.who.int/healthinfo/global_ burden_disease/en/.

8. Walker GA, Andrea S, Faigenbaum AD, Myer GD. Physical inactivity in youth can exercise deficit disorder alter the way we view preventative care. ACSMs Health Fit J. 2018;22(2):42-6.

9. Lee BY, Adam A, Zenkov E, Herstenstein D, Fergunson MC, Wang PI, et al. Modeling the economic and health impact of increasing children's physical activity in the United States. Health Aff (Millwood). 2017;36(5):902-08.

10. Educação Física-Obrigatoriedade da Disciplina. [citado 2018 Jul 10]. Disponível em: http://portal.mec.gov.br/inicio/323secretarias-112877938/orgaos-vinculados-82187207/12962educacao-fisica-obrigatoriedade-da-disciplina.

11. Gallotta MC, Emerenziani GP, Iazzoni S, Iasevoli L, Guidetti L, Baldari C. Effects of different physical education programmes on children's skill- and health-related outcomes: a pilot randomised controlled trial. J Sports Sci. 2017;35(15):1547-55.

12. Leitão MB, Nóbrega ACL, Carvalho T, Oliveira MAB, Teixeira JAC, Lazzoli JK, et al. Posicionamento Oficial da Sociedade Brasileira de Medicina do Esporte: Atividade física e saúde na infância e adolescência. Rev Bras Med Esporte. 2000;6(6):215-20.

13. Fröberg A, Raustorp A, Pagels P, Larsson C, Boldemann C. Levels of physical activity during physical education lessons in Sweden. Acta Paediatr. 2017;106(1):135-41.

14. Meyer U, Roth R, Zahner L, Gerber M, Puder JJ, Hebestreit $\mathrm{H}$, et al. Contribution of physical education to overall physical activity. Scand J Med Sci Sports. 2013;23(5):600-06.
15. Hollis JL, Sutherland R, Williams AJ, Campbell E, Nathan $\mathrm{N}$, Wolfenden $\mathrm{L}$, et al. A systematic review and meta-analysis of moderate-to-vigorous physical activity levels in secondary school physical education lessons. Int J BehavNutr Phys Act. 2017; 24;14(1):52.

16. Drenowatz C, Steiner RP, Brandstetter S, Klenk J, Wabitsch M, Steinacker JM. Organized sports, overweight, and physical fitness in primary school children in Germany. J Obes. 2013;2013:1-7.

17. Brusseau TA, Hannon J, Burns R. The Effect of a Comprehensive School Physical Activity Program on Physical Activity and Health-Related Fitness in Children From LowIncome Families. J Phys Act Health. 2016;13(8):888-94.

18. Errisuriz VL, Golaszewski NM, Born K, Bartholomew JB. Systematic review of Physical Education-based physical activity interventions among elementary school children. J Prim Prev. 2018;39(3):303-27.

19. Gallant F, O'Loughlin JL, Brunet J, Sabiston CM, Bélanger M. Childhood Sports Participation and Adolescent Sport Profile. Pediatrics. 2017;140(6).e20171449.

20. The Cooper Institute for Aerobics Research. Fitnessgram Manual de Aplicação de Testes. Lisboa: Ed. Portuguesa, Faculdade de Motricidade Humana; 2002.

21. Trigo MMP. Aptidão física e composição corporal. Estudo em raparigas dos 11 aos 15 , praticantes e não praticantes de futsal [tese de mestrado]. Portugal: Universidade do Minho; 2016.

22. Fairclough SJ, Stratton G. A review of physical activity levels during elementary school physical education. J Teach Phys Educ. 2006; 25(2):240-58.

23. Telama R, Yang X, Leskinen E, Kankaanpää A, Hirvensalo M, Tammelin T, et al. Tracking of physical activity from early childhood through youth into adulthood. Med Sci Sports Exerc. 2014;46(5):955-62.

24. Ward JK, Hastie PA, Wadsworth DD, Foote S, Brock SJ, Hollett N. A Sport Education Fitness Season's Impact on Students' Fitness Levels, Knowledge, and In-Class Physical Activity. Res QExerc Sport. 2017;88(3):346-51.

25. Khodaverdi Z, Bahram A, Stodden D, Kazemnejad A. The relationship between actual motor competence and physical activity in children: mediating roles of perceived motor competence and health-related physical fitness. J Sports Sci. 2016;34(16):1523-29.

26. Robinson LE, Wadsworth DD, Webster FK, School Reform: The Role of Physical Education Policy in Physical Activity of Elementary School Children in Alabama's Black Belt Region. Am J Health Promot. 2017;8(Suppl 3):S72-S76.

27. Telford RM, Olive LS, Cochrane T, Davey R, Telford RD. Outcomes of a four-year specialist-taught physical education program on physical activity: a cluster randomized controlled trial, the LOOK study. Int J Behav Nutr Phys Act.2016;13:64.

28. Lopes VP, Stodden DF, Rodrigues LP. Effectiveness of physical education to promote motor competence in primary school children. Phys Educ Sport Pedagogy. 2017;22(6):589-602.

29. Ferreira FS, Mota J, Duarte JA. Patterns of physical activity in Portuguese adolescents. Evaluation during physical education classes through accelerometry. Arch Exerc Health Dis. 2014;4(2):280-5.

Received: 28/12/2018 Approved: 10/07/2019

\section{Quote this article as:}

Gonçalves MJR, Santos CR, Silva CC. The impact of systematized physical activity on parameters of health-related physical fitness in schoolchildren aged 8 to 11 years. Rev Bras Ati Fis Saúde.2019;24:e0072. DOI: 10.12820/rbafs.24e0072 